\title{
Diverse Ecological, Economic and Socio-Cultural Values of a Traditional Common Natural Resource Management System in the Moroccan High Atlas: The Aït Ikiss Tagdalts
}

\section{PABLO DOMINGUEZ ${ }^{1 *}$, ALAIN BOURBOUZE ${ }^{2}$, SÉBASTIEN DEMAY $^{3}$, DIDIER GENIN $^{4}$ AND NICOLAS KOSOY 5}

${ }^{1}$ School of Anthropology and Conservation

Marlowe Building, University of Kent

Canterbury, Kent CT2 7NR, UK

Email:P.Dominguez@kent.ac.uk

* Corrresponding author

${ }^{2}$ Institut Agronomique Méditerranéen de Montpellier (France)

${ }^{3}$ Institut National Agronomique Paris-Grignon (France)

${ }^{4}$ Institut de Recherche pour le Développement, Laboratoire Population-

Environnement (France)

${ }^{5}$ McGill School of Environment and Dept. of Natural Resource Sciences, Faculty of Agricultural and Environmental Sciences, McGill University

\begin{abstract}
This study examines the multiple dimensions of the agdal system, a traditional Berber form of environmental management that regulates access to communal natural resources so as to allow the regeneration of natural resources. In fact, this ingenious system of agro-pastoral land rotation is ultimately beneficial for the conservation of the bio-physical environment, the performance of the present-day local economy and the maintenance of prevailing social cohesion and cultural coherence. Hence, agdals constitute a key element for the reinforcement of the sustainability of existing agro-pastoral societies and ecosystems, but need to be better understood in order to explore necessary adaptations in the changing world of today.
\end{abstract}

\section{KEYWORDS}

Amazig, religion, Morocco, Agdal, commons, environment 


\section{PABLO DOMINGUEZ ET AL.}

\section{INTRODUCTION}

Local institutions linked to communal natural resource management have been studied for several decades and their contributions to 'sustainability' have been internationally recognised (Folke et al., 2007; Ostrom, 1990; Neves-Garca, 2004). However, few studies have analysed the existing traditional institutional agdal systems of communal natural resource management found in the Berber area of the Maghreb (Ilahiane, 1999; Venema 2002; Bourbouze, 1997; Cordier and Genin, 2008), even less so in a fundamentally multidimensional way (Auclair et al., 2007; Dominguez, 2010). The agdal can be defined as a system of seasonal prohibitions that limits access to one or more agro-sylvo-pastoral resources in order to allow them to recover from direct or indirect human pressure during their most critical period of growth. In fact, the agdal management system seeks above all to optimise the complementary use and productivity of the resources and to ensure their continuity. The prohibition of the removal of renewable resources during these critical periods allows the resource to grow exponentially and at the same time leaves it time for regeneration (in the case of the pastures, the flowering and establishment of new seeds), thus ensuring the continuity of the ecological cycles. But it also indirectly leads in many cases to other ecological benefits. One example of this is the maintenance of dense vegetal cover, a consequence of the biomass removal restrictions as shown in the case of forest agdal in the Ait Bouguemez (Hammi et al., 2007). Another is the appearance of higher rates of biodiversity conservation inside the agdal managed spaces than in comparable areas without or with less agdal management (Kerautret, 2005; Alaoui-Haroni, 2009; Dominguez and Hammi, 2010).

At economic level, various small scale studies have also made it evident that the contribution of collectively managed areas can have a positive impact on local economies (Ostrom, 1990; Neves-Garca, 2004). In the case of forest agdals, Genin et al. (in press) show that the leaves from the forest of Querqus ilex in the Ait Bouguemez valley represent an important complementary forage resource during winter snows when other pastoral resources (herbs, bushes, etc.) are covered by snow or in latency. In addition, in certain villages, the surpluses of pastoral agdals are exchanged for water use rights between neighbouring tribal fractions (Romagny et al., 2008). Pastoral agdals also contribute to agricultural enrichment through the recycling of nitrates and derivates that come from the highlands through animal manure (Demay, 2004).

With regard to social justice, the season and the duration of the prohibition of the agdal, the resources, and the spaces concerned by this prohibition, are decided solely by the tribal assembly (jmaa) on the basis of its own history, territorial heritage, political structure, knowledge and annual economic strategies, with the aim of ensuring the continuity of the local agro-pastoral system. This being so, as long as the tribal assembly (jmaa) continues to exist, the opening of the 


\section{THE AÏT IKISS TAGDALTS}

agdal will always have to wait until the date agreed by the majority (Ilahiane, H. 1999; Auclair et al., 2007). Hence the agdal guarantees a certain security of access to the group in especially critical moments and the continuity of resources for the benefit of the community as a whole. Nevertheless, this is not always so, mainly in the case of big tribal or intertribal agdals. Generally, in these cases, when agreement or respect of the rule are not reached by the community of users, the local governmental authorities play a referee role.

This ingenious system of agro-pastoral land rotation, where one space or resource is banned to users at a certain period while another is still available, is also intimately linked to a complex worldview. In fact the cultural and religious heritage underlying the agdal in Morocco constitutes a key element for reinforcing the sustainability of the current uses of natural resources and the social representation system which is strongly embedded in the agdal system (Mahdi and Dominguez, 2009; Simenel, 2008). For example, as we will describe later and as other authors have shown for many other High Atlas populations (Hammoudi, 1988; Rachik, 1992; Mahdi, 1999), religion strongly structures the pastoral life of which the agdal is a central part.

As we can see, failure to take into account the complexity of the agdal would be to distort any analysis of it. Hence, our main hypothesis in this article is that the agdal must be analysed multidimensionally if we are to understand its value fully. It is the aim of this paper to examine the many dimensions of the agdal system through a case study of the Ait Ikiss people in the High Atlas of Marrakech (central Morocco), who use different small agdals (locally called tagdalts) combined with a particular system of land rotation. We first explore the spatial functioning of this system, then estimate the contribution to livestock feeding of a small scale communal agro-pastoral territory managed under this system, and finally we assess the social and cultural importance of the tagdalt system as a whole.

\section{CONTEXT OF THE STUDY.}

The study area is the territory of the Ait Ikiss people, located at the heart of the High Atlas, less than 50 kilometres from the city of Marrakech. The climate is typically Mountain Mediterranean, with precipitation of about $500 \mathrm{~mm} / \mathrm{year}$, and monthly mean temperatures that range from $0 \mathrm{C}^{\circ}$ in December to $20 \mathrm{C}^{\circ}$ in July, and which strongly vary within the year and according to the geographical location. Like any other high mountain area, it is compartmentalised within a vegetation altitudinal gradient from about 1,300 to $3,000 \mathrm{~m}$. This includes, from bottom to top, Mediterranean forest, scrub and brush, humid highland pasture, semi-dry steppe with strong presence of cushion shaped xerophytes, and at the mountain top, rough pasture and highly resistant Juniper. 
PABLO DOMINGUEZ ET AL.

This population is characterised to a greater or lesser extent by a traditional tribal organisation, previously described by British anthropologists as segmentary structure (Gellner, 1969). It is typified by fitting one social group (or segment) into another, from the smallest to the biggest, like a set of Russian dolls (EvansPritchard, 1970). For example, the Ait Ikiss continue to organise themselves in tribal fractions, sub-fractions, villages, clans and nuclear families. The population speaks Tachelhit, a South Moroccan Berber dialect. Most of the men speak Arabic as do some of the women, especially the youngest. It has been estimated (Bellaoui, 1989) that the relative contribution of the agropastoral sector to the local income of the Zat valley (the Ait Ikiss included) is approximately 75 per cent, which is usually combined with seasonal emigration or specialised local work such as masonry or smithy work or similar. Livestock consists mainly of cows, sheep and goats.

The Ait Ikiss group that we have studied comprises about 640 people, who occupy four different habitats: Azgour/Tifni, Ikiss, Warzazt and Yagour n'Ikiss (Figure 1). The Aït Ikiss group is patrilineal, as in other Berber societies. All decisions regarding a household's use of the agro-pastoral resources are taken by the male heads of each household, and in their absence, by the oldest adult male
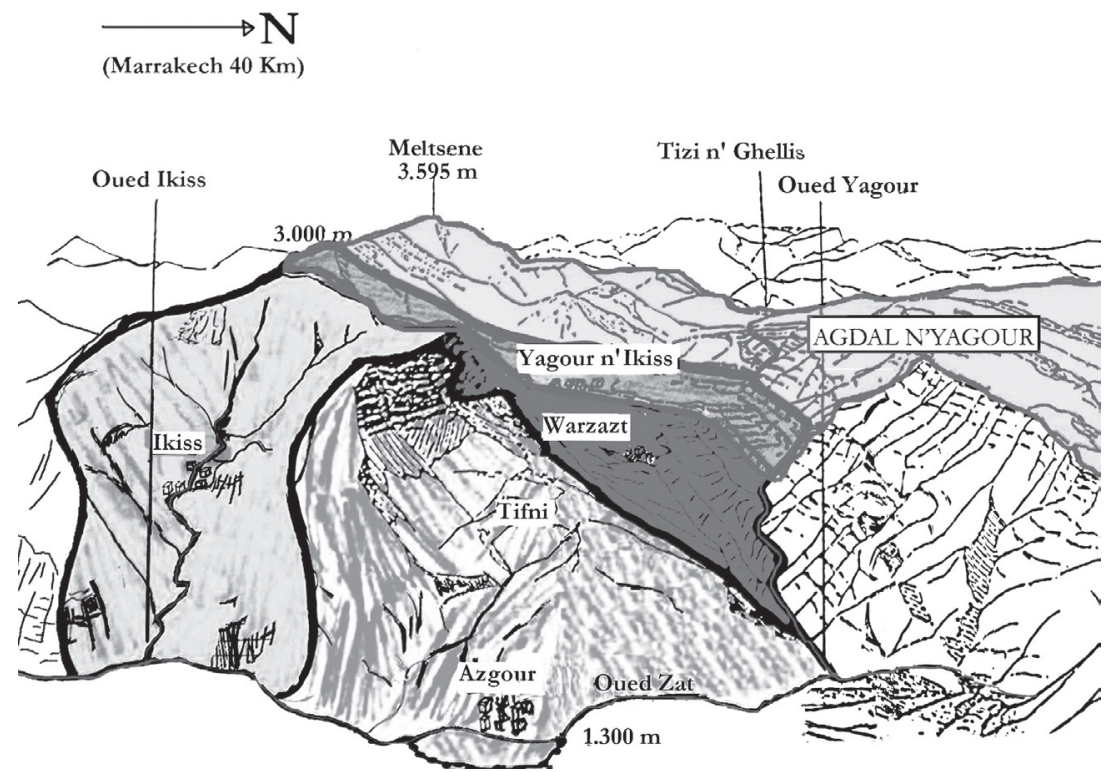

FIGURE 1. Territory of the Ait Ikiss and their four habitats (based on Dresch, 1939) 


\section{THE AÏT IKISS TAGDALTS}

of the family. The Aitt Ikiss, like the rest of the mountain Mesioui, are mainly defined in Morocco as non-orthodox Sunni Muslims and sustain beliefs and practices that are the result of a long cohabitation between pre-islamic religions and earlier Islam. They organise their activities and manage their communal territory through tribal assemblies called the jmaa. The seasonal agdal prohibitions imposed among their territories are decided by the jmaa, and nominated members serve as guardians (locally called Ait Rbains). When the Ait Rbains report a delinquent, graduated sanctions are usually established by the jmaa, according to the different types of offences. The extensive pastures of the Ait Ikiss and the dense humid prairies of the highlands mainly situated in the Yagour n'Ikis habitat (about $5 \mathrm{~km}^{2}$ ) are the most important basis for the existence of the tagdalt system, but other spaces and resources are also important to this system as we will see later.

\section{METHODOLOGY}

\section{Data collection}

The qualitative data of this paper was collected through intermittent participative observation from 2004 to 2008, throughout all agro-pastoral seasons, adding up to one whole year of co-habitation with the Ait Ikiss people. More systematic open-ended interviews concerning the animal production structure and the uses of the Ait Ikiss territories were carried out with the assistance of Berber native speakers who helped with the translation and enquiry process during the months of June to September of 2004 and 2007. Questions were asked on topics such as the agro-pastoral uses and production of the territory, the main vegetal and fruit production per year, the way sheep, goats and cows were managed, number of adult animals, their selling prices at the local market, ownership of manufactured goods and each household's dependence on remittances.

Most interviews were carried out with the male household heads living in the village of Warzazt. In the case of absence of the male household head, the interview was carried out with the oldest man of the household present at the moment of our arrival at the house. Male household heads were mainly targeted due to the nature of the data (i.e., choosing the opening date of the agdal, the number of animals owned by a family, the broad agro-pastoral production decisions or the most important religious rituals). The systematic open-ended interviews were carried out with 83 of the 107 households that compose the Ait Ikiss, which represents about 77 per cent of its population and almost 100 per cent of the owners of livestock using the tagdalt system. The remaining 26 households were not interviewed because there was no male adult present at the time of the survey, mostly due to seasonal migration. 


\section{PABLO DOMINGUEZ ET AL.}

\section{RESULTS}

Results have a threefold focus: (i) the functioning of the Ait Ikiss agro-pastoral system, by mean of a spatial analysis; (ii) the contribution of the main Ait Ikiss pastoral territory to the nutrition of livestock; and (iii) the socio-cultural aspects of the system.

\section{Space analysis of the tagdalt system of the Ait Ikiss}

This area with heavy winter snow and harsh climate suffers from a fodder shortage for the herds during the winter and another at the end of summer in dry years. It is thus a challenge for these agro-pastoralists to manage the use of the territory in time and space in order to meet the nutritional needs of their livestock, and to ensure soil fertility in the cultivated areas by means of animal manure (Genin et al., in press). With this in mind, agro-pastoralists regulate access to the resources by means of various agdals. All these agdals, as a whole, are locally named tagdalts (small agdals) by comparison with the large tribal agdals which are managed by several villages. The agro-pastoral calendar in turn reflects the choices of the different herding restrictive periods which dictate the rhythm of displacements of animals and people, in relation to the availability of different natural resources throughout the year.

\section{September-28 March}

On September 28th and after two months of herding prohibition, the agdal of Ikiss opens. Until this date the prohibition concerned not only herding but also gathering walnuts as well as some other fruits. Starting from this date, all spaces are opened and there are multiple movements. In any case, it is nut gathering at the end of September which dictates the main movement of peoples (principal

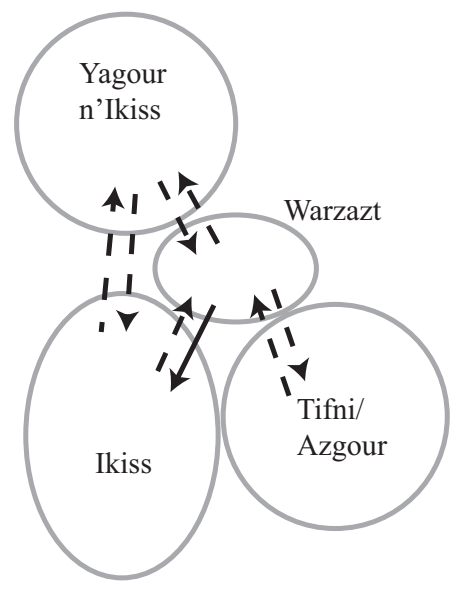
displacement is always indicated with a continuous arrow on our diagrams). At this time, most of the people leave for Ikiss because that is there where most of the walnut trees are located. The village of Ikiss is the location where most of the Ait Ikiss population spends the autumn and winter seasons. One of the reasons is the walnut gathering, but also because it is located at rather low altitude $(1,700 \mathrm{~m})$, and the weather is not as cold as at Warzazt $(2,000 \mathrm{~m})$ or Yagour n'Ikiss (2,200 m). Another other important reason for living in Ikiss is because it is the hometown of the entire group (hence their 
name, Aït Ikiss meaning 'those from Ikiss') from where, throughout the last century, some have moved to the other habitats. Thus Ikiss has more well-built houses and is more better-suited for spending the winter. Tifni is mainly an area for sheep-folds and Azgour, even if lower and with a better winter climate, has less agricultural lands and is an old sheep-fold transformed into a village only at the turn of the last century after the construction of the road at the bottom of the valley, and is less well equipped in infrastructure.

\section{March-20 April (approximately)}

On March 28th the whole of Yagour is put in agdal for three months (areas under the agdal prohibition are marked with discontinuous circles), in order to

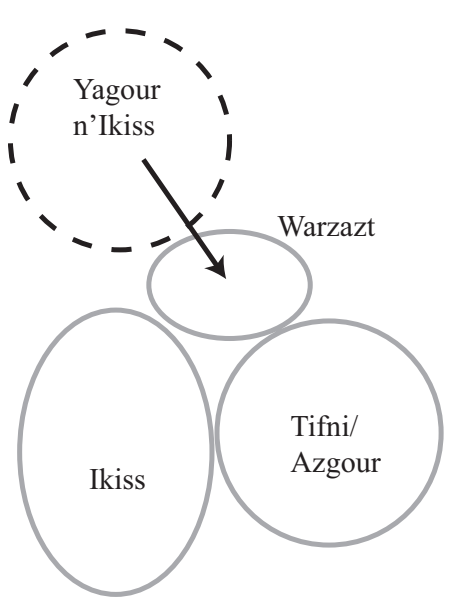
favour growth of graminaceous plants. In fact, the prohibition takes several weeks to become effective because there are always herders who stay a little longer and attempt local political manoeuvres to stay as long as they can. In practice, the prohibition is only imposed approximately from mid-April on every year. At this time, approximately fifty adult shepherds of the Aït Ikiss leave the Yagour. People who have been herding their sheep in the Yagour come down to Warzazt at this time. Caprines and bovines are kept all the year except in late spring and summer away from the colder regions, mostly in Ikiss and a very small minority in Azgour.

20 April (approximately)—20 May (approximately)

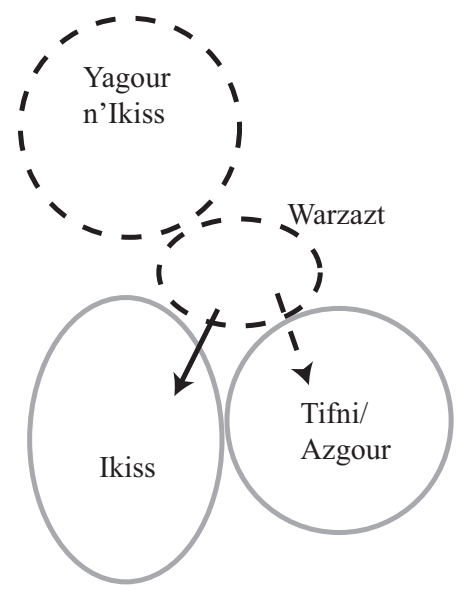

Warzazt is the second highest habitat of the Ait Ikiss, and the most extensively cultivated. According to the shepherds, the month of May is the most critical period for the growth of the pastoral plants at Warzazt. Thus, in mid-spring, the herding prohibition is also imposed on Warzazt, in order to allow the grass to grow back, particularly the strips between the cultivated fields. At this time of prohibition, the twenty families which have their main house in Warzazt (mainly sheep herders) are obliged to transfer their herds down to the Tifni sheep-folds at 1,900 $\mathrm{m}$ (on the way to Azgour), and especially to Ikiss at $1,700 \mathrm{~m}$. 
PABLO DOMINGUEZ ET AL.

\section{May (approximately)—10 July (approximately)}

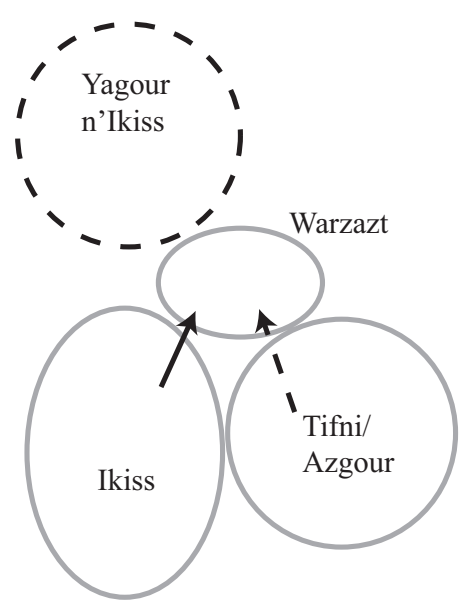

After one month of agdal, Warzazt opens again (around 20 May). This induces an opposite migration, of people going up from Ikiss or Tifni towards Warzazt, where about a month later (at the end of June) the barley harvest starts. At this period, virtually all the Aït Ikiss leave in transhumance towards the highlands. Also the two shops in Warzazt which had been closed since September reopen with the arrival of the population. In fact, the two shop owners (former local herders themselves) and the fqih/imam, move with the group from Ikiss to Warzazt. Just before, they sacrifice animals in the hope of a good stay in the high pastures.

\section{July (approximately)—28 September}

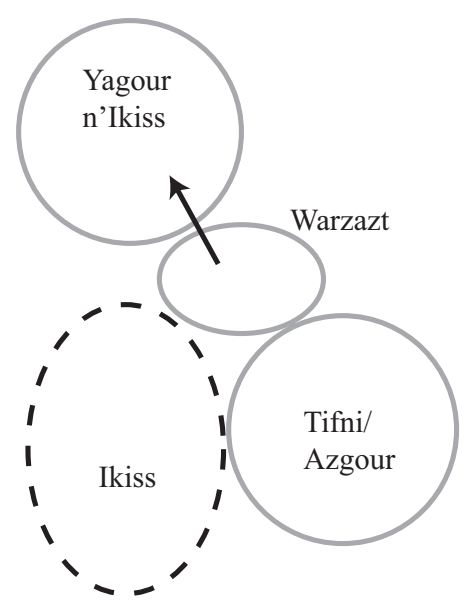

At the beginning of summer, the Yagour n'Ikiss is opened. Depending on the ecological conditions of the year, Yagour opens at around the beginning of July, according to the decision taken by the jmaa. The transhumant Ait Ikiss take their animals up the slopes leading to the richest summer pastures and prepare to enjoy the most abundant period for the community, which is seen by many children as a holiday period. The opening of the agdal of Yagour is an event of great local importance because it offers excellent grazing for the herds, and also an opportunity for people to meet the inhabitants of other lower villages after over 9 months of separation. Other ritual sacrifices of animals

and festive events also take place at this time. In the areas most favourable for agriculture, the harvesting of cereals is carried out just a few days before the opening of the Yagour or in the following weeks. At the same time, the Ait Ikiss assembly authorises the collection of fodder for the winter season, where (only during the first three days after the opening of the Yagour) families are allowed to mow as much pasture as they can. A few weeks later, in mid-July, and following the same community logic, the Ikiss area is put in agdal too and herding remains prohibited once again. This prohibition particularly helps to 


\section{THE AÏT IKISS TAGDALTS}

protect fruit trees in the valley that are ripening at just this time, and also the lowland pastures that had previously been grazed, and that may be severely affected by the summer drought. Only every 15 days or so, the fruit tree agdal at Ikiss is lifted to prevent the rotting of certain fruits that had already matured on the trees before 28 September, when the whole agdal prohibition at Ikiss is officially lifted. In this way, the end of the cycle is reached, the whole system returns to the situation shown in the first diagram and most of the people come back to Ikiss for the gathering of the walnuts.

As we have seen, the dates and the access rules to the renewable resources of the Ait Ikiss are closely related to pastoral requirements, and also those of agriculture and to the system of production (availability of good pasture, mowing of fodder for the winter, fruit trees, cereals, horticulture, grass strips between the terraces, animal manure as agricultural fertiliser, etc.). We show below a calendar for the various tagdalts of the Ait Ikiss in relation with the agricultural calendar. This makes clearer the overlap between the tagdalt and the agricultural calendar.

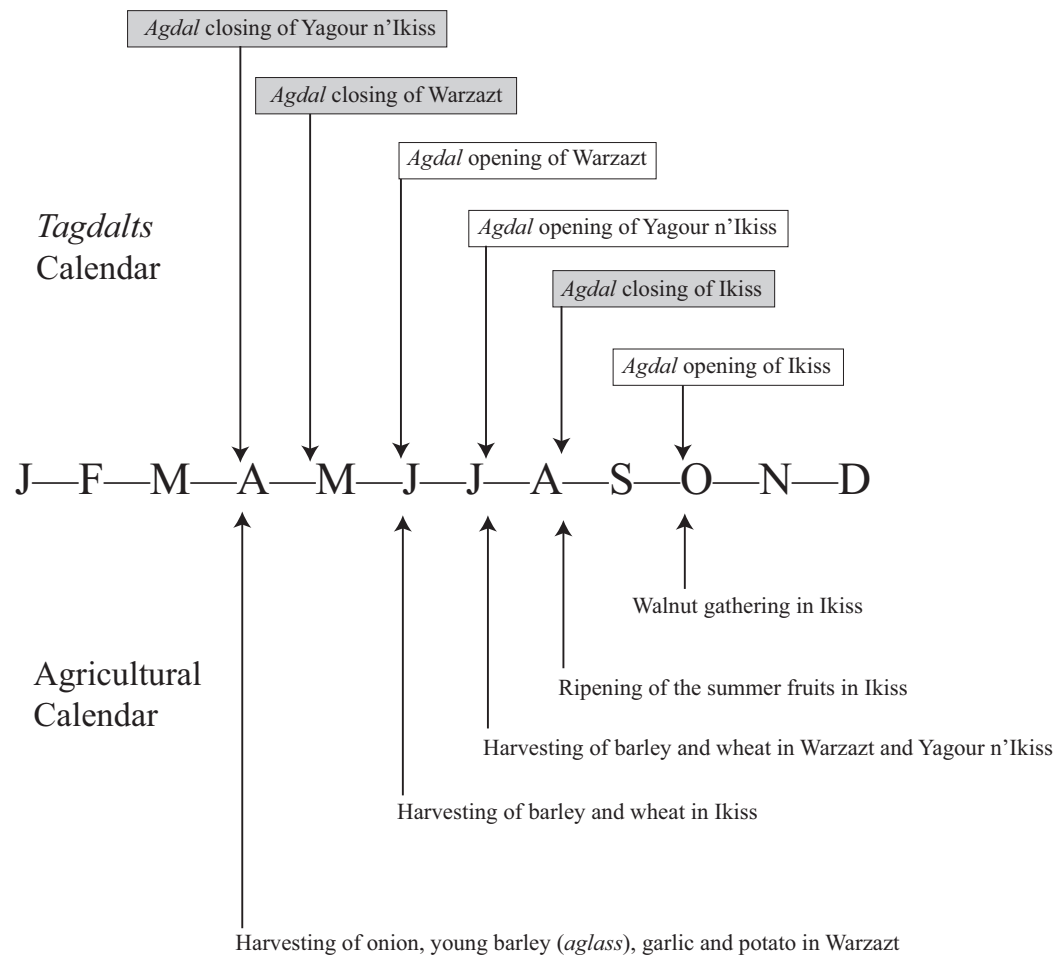




\section{PABLO DOMINGUEZ ET AL.}

\section{Contribution of the Yagour territory to the Ait Ikiss livestock's nutritional requirements}

We have attempted to assess the contribution of the Yagour n'Ikiss to the livestock's food requirements by quantifying the grazing days spent by different types of livestock within this territory. The reason why we chose to focus on the Yagour for this part of the analysis is because it is the most important herding territory for the group and therefore the most fully representative of their pastoral tagdalt system. We calculated the nutritional contribution of the Yagour n'Ikiss for the different types of livestock by counting the days passed on the Yagour by each type of animal, on the assumption that their grazing is not complemented with other feed resources during this period when the annual rainfall has been average. In fact, except in years of severe drought, it would appear that all animals obtain from the Yagour all their nutritional requirements (Demay, 2004).

The number of head of livestock grazing on the Yagour n'Ikiss is very high (almost all the community's animals are there in summer) and corresponds to a little more than 3,000 animals including sheep $(1,261)$, goats $(1,794)$ and cows (138), corresponding to almost 3,600 Ovine Units (Jarrige, 1980). At the same time, we found that the food requirement of sheep appears to be strongly dependent upon the forage resources provided by Yagour since these represent 42 per cent of their annual food requirement. On average sheep spend 5 months per year feeding exclusively on the Yagour ( $5 / 12$ months $\approx 42$ per cent). This is an important contribution to the local economy since sheep represent the main cash income source. The price of a goat is less than half that of a sheep, and cows mainly contribute to the local economy only through consumption within the community, and a calf every two years. Contribution of the Yagour to the goats' annual diet is about 28 per cent, since they spend on average 3.3 months per year feeding on the Yagour (3.3/12 months $\approx 28$ per cent), while cows obtain only 17 per cent of their annual food requirements from this territory due to their shorter stay in the highlands (on average 2 months per year). Overall, this analysis reveals the importance of one of the four pastoral lands of the Aït Ikiss, and explains quite well one of the main reasons why so much care and protection is devoted to the territory since it plays a crucial role with regard to feeding requirements at critical periods.

\section{Cultural values associated with the agdal of Yagour}

These spatial and quantitative analyses can only shed light on some aspects of the complexity of this management system; it is necessary to consider the symbolism of the agdal in order to achieve an in-depth understanding. The place of the saints in the tribal societies of Morocco and the North of Africa is well known (Montagne, 1930; Bel, 1938; Gellner, 1969; Mahdi, 1999). The 


\section{THE AÏT IKISS TAGDALTS}

shepherds traditionally put themselves and their herds under the protection of the local Muslim saints. The saint granted fertility and prosperity for cattle and the community. In compensation, shepherds honoured the saint's grave and those of his descendants with various gifts and sacrifices. For example, Gellner (1969) showed how, by the physical location of their mausoleums (at the borders between tribes), many saints and especially their descendants played a role of referee in conflicts, acted as guarantor for various types of agreement and assured safe passage to the high pastures at the end of the agdal prohibition each year.

The tagdalt system of the Ait Ikiss follows the same pattern, and is traditionally placed under the patronage of certain saints (Dominguez, 2010). We will mainly refer here to the Saint Sidi Boujmaa and his descendants, who had the great agdal of Yagour under their patronage, and still have a certain symbolic importance in this matter. This Saint is buried in a village of the same name. The village is located at one of the symbolic gateways to the Yagour, within the territory of the tribe of the Mesioua, and its importance derives from its traditional crucial relationship with the agdal of Yagour. In fact, local tradition asserts that all the different saints of the Yagour came to an agreement to give Sidi Boujmaa the key to the agdal. Therefore, no one could enter the agdal before his descendants announced it at the weekly market of the Arbaa Tighdouine. This was the case until about the 1970s, when unusually high demographic growth, economic transformation, possible climate change and cultural transformations, among other factors, forced a change. The decline of traditional religious observances triggered at that time is due to strong social pressure that resulted in their being seen as archaic and out of phase with true Islam. This perception may be related to the introduction of compulsory state schooling, generational cultural change, the rise of a more orthodox form of Islam that is intolerant of the veneration of saints, television, the market economy and other agents of cultural globalisation such as NGOs and local government. Nevertheless, the saints are still seen today by most of the local population as the symbolic mainstay and guarantor of the order that prevails in the agdal and the organisation of the transhumance. Access to the agdal, with its dates of opening and closing, is thus closely related to the person of the Saint, who is portrayed as a sacrosanct character who confers dignity and authority on the rules of agdal. This same tradition specifies that it is the zaouia (the brotherhood) of Sidi Boujmaa which keeps the papers certifying the rules of access to the agdal. This same institutional and symbolical organisation appears often with other saints, when moving to or from other areas before and after the various agdal prohibitions. As indicated above, rituals such as maarouf (animal sacrifices in honour of the saints), are performed throughout the pastoral cycle and in particular at key moments such as the opening of various agdals.

After the 'prohibition period' of the agdal consecrated by the saints, in which fear and malediction are imposed on the agdal area, with the arrival of 
PABLO DOMINGUEZ ET AL.

the agdal opening time, there is a new sacred 'permissive period'. The opening of the agdal and the stay of the shepherds in the mountain pasturelands is accompanied by important festivities and recreation and high ritual activity. Also at the opening of new areas for agriculture or the inauguration of water channelling, and especially when the shepherds return to their summer farms with the best pastures, major or minor rites are celebrated to seek reconciliation with the genie that had occupied these areas during their absence. For example, it is reported that some herders slaughter small ruminants when they arrive at the agdal in honour of Allah and the saints. Others cook couscous and divide it collectively. Others offer pieces of entrails to the toads symbolising the devils of the places. All of this is done in the hope of peaceful resettling in the pastoral sites. Despite an evident decline in of these practices, the Ait Ikiss population continues to honour its saints through gifts offered near the graves or mausoleums in the form of grains, blood sacrifices and so on. In compensation, from the Saint they hope to obtain prosperity, fertility of their cattle and the protection of the group and its territory.

Concerning the sacredness of the territory, like the sacred legislation that governs the tagdalt system, the area managed by the agdal is also sanctified. This sacred status and horm (prohibition) generally decreed by the saints is reinforced by a sacred topography of the agdal managed territories. Popular narratives reinforce its sacred character, and refer to other magic or religious elements, in the hope of offering proof and attempting to intimidate the unbelievers. There are sayings such as: 'a man dressed in white on his white horse appears every year when the agdal prohibition is introduced at the Yagour, to safeguard the pastures from the dishonest by punishing the offenders in different ways'. Or 'the 365 saints turning around the Yagour to ensure the supervision of the agdal with their horses and their camels'. Some of the different saints located within the Yagour, as many as the days of the year, have tombs more or less clearly marked within and in the vicinity of the Yagour, but others do not have any place of sepulchre, just natural features or piles of stones that serve as a reference. These Saints are supposed to be responsible for overseeing the good functioning and the respect of the tagdalts of the Ait Ikiss.

In the Aï Ikiss territories, many areas are subject to strong local religious beliefs, which are not without ecological consequences. For example, some sacred agdals located near the mausoleums of the saints or the cemeteries of the different villages, are provided with abundant vegetation, and are permanently protected from consumption by livestock and from harvesting, by the sole power of the beliefs and social prohibitions that protect these sacred places. They constitute useful seed banks and plant dispersion areas. Other elements also are also involved in this sacred geography of the territory. For example, there are more or less sacred or magic water springs, which guarantee health and the Baraka (benediction). Or spaces populated by genies, associated most 


\section{THE AÏT IKISS TAGDALTS}

often with humid areas or areas far away human habitats. These genies are not necessarily described as malevolent beings, but they inspire strong fear, and they are especially present during the various prohibitions of the tagdalts.

\section{DISCUSSION}

Being universal features of the agdal, we have emphasised the three aspects that comprise the added value of the agdal management system: (i) conservation of the bio-physical environment; (ii) the performance of the current local economy; and (iii) the maintenance of current social cohesion and cultural coherence. The conservation of the bio-physical environment is favoured by non-intensive exploitation of rangelands that is characterised by a relatively wide dispersal of cattle in the various grazing areas throughout the year, as we have seen. The only exception is at the opening of the great agdal of Yagour, in the first weeks of summer, when most of the sheep, cows and goats are concentrated within the same area of about 40 hectares with a particularly rich sward. In any case, the intensive herding at this time is well supported by the vegetation that is at its most abundant and sumptuous, with grasses reaching almost one metre in height and a density that completely conceals the ground. The generally extensive approach to ecosystem management culminates precisely in the tagdalt system which allows to each type of area an annual resting period. This herding prohibition makes it possible for the vegetation to accomplish its phenological cycle, allows the establishment of young seeds and thus favours the continuity of the ecosystems and provision of the associated ecosystem services (Aloui and Alifriqui, 2009). Hence, the vegetation cover and vegetal diversity found in the Ait Ikiss tagdalts are higher than those found in similar areas outside agdals in 'open access' or under degraded agdal management (Dominguez and Hammi, 2010). Because of this, the tagdalts also seem to be a helpful governance regime to combat soil erosion. Finally, the system of different agdals, closed and open at different times, results in an ecological mosaic effect throughout the whole territory of the Ait Ikiss due to a specialised and differentiated use of the four areas, which is considered as a favourable feature in landscape ecology and a characteristic of the historical 'design' of Mediterranean landscapes (Blondel, 2006).

With regard to the performance of the local economy, we found that the agdal management system favours the sustainability of the pastoral economy since it ensures the continuity of the current ecosystems, as explained above. In fact, the current system of ecological and economic equilibrium would simply collapse and change in character if the tagdalts disappeared, since without a resting period the different areas would lose part of their carrying capacity. But the economic benefits derived from the agdal are not only constrained by the ecological sustainability of the system that permits the continuity of the economic 


\section{PABLO DOMINGUEZ ET AL.}

system. For instance, at a higher organisational level, all Aït Ikiss benefit from the agdal system that guarantees access of rangelands to the different shepherds, and prevents conflicts through the regulation of competition between the different users. Zootechnical and ecological arguments are of limited importance when the social organisational character of the agdal is taken into account, and this is a key part of the economic system, if not one of the most fundamental.

We also found that the main pastoral territory, the Yagour, can contribute up to 42 per cent, 27 per cent and 17 per cent of the diet of the sheep, goats and cows, respectively. In this context, it is important to highlight the economic weight in the agro-pastoral gross income that derives from this especially rich pastoral territory, due to its importance for animal nutrition. Less relevant in terms of forage production but similar in their pattern of land exploitation, the other sectors of the Ait Ikiss together provide forage and income to the agropastoral system in a similar way. Such an important fodder contribution of the four agdal managed areas is especially significant as it must be noted that the agro-pastoral economy represents about 70 per cent of the total economy of the community (Dominguez, 2010) and thus greatly determines the current landscape and natural resource management system in the region.

Moreover, the fodder contribution accumulated after the herding prohibitions in all the territories subject to the agdal arrives in late spring, summer or at the end of summer, when the other pastures are dry, and when fodder demands are higher as young animals are still suckling or mothers are already pregnant with the second annual offspring. This gives an added economic value to the fodder that has been accumulated during the different agdal prohibition periods. In any case, monetary accounting is difficult (if not impossible) with such a multifaceted system as the agdal, which involves diverse ecological, economic and cultural aspects, in a society that capitalises weakly on its own production. And even if we had wished to focus solely on the monetary aspects of the system, the findings would have presented an underestimation of the agdal managed territories' contribution to the Aït Ikiss' overall household economy. In fact, the actual figures would have been higher than those found in this article (i.e. higher feeding rates in summer than in winter, production of milk, wool, manure, honey, and water, are not easily taken into account). However, the fact that the real contribution of the pastoral territories would be higher than that derived just from the nutritional percentages that we have calculated in Section 4 only reinforces the fact that the agdal system is a fundamental element of the performance of the current local economy.

Nevertheless, as we have seen, it would be highly reductionist to stop the analysis at this point, since the tagdalt system has other functions that are less directly materialistic or quantitative. It involves other social and symbolic functions that are not quantifiable. First of all, it allows an equitable right of access to pasture for all the community and guarantees a certain degree of social justice 


\section{THE AÏT IKISS TAGDALTS}

among herders. Even if it is always the richest cattle owners that benefit most from the communal pastoral resources, they will never be allowed to herd during the critical prohibition periods. While the majority still maintains the rule of the agdal, all (rich and poor) will be equally capable of meeting their respective fodder needs at the opening of the different tagdalts. At the same time, the tagdalts also play a role in identity building and the feeling of belonging to a certain group that confers rights and duties over those territories. On a more cultural level, the agdal is also one of the main vehicles of a complex belief system that we have briefly described and that gives protection and meaning to the local social organisation and livelihoods. As we have seen, transhumance towards the agdal-managed territories is the occasion of an intensive deployment of social and cultural activity, accompanied by an atmosphere of religious celebrations. All of this takes place in a highly multidirectional and interconnected way, and contributes to consolidating the collective discipline that ensures the success of this management model. This is a type of social organisation where the sacred holds an important place and gives meaning to material activities. The tagdalts for their part entail meanings and rites that periodically bring people together, contribute effectively to social cohesion and guarantee the continuity of the cultural order.

\section{CONCLUSION}

This study has examined the multiple dimensions of the tagdalt system of the Ait Ikiss with the aim of achieving a better understanding of an ingenious agro-pastoral system which is intimately linked to a complex worldview. This longstanding endogenous resource management system appears to fulfil almost all the accepted institutional principles that are considered to be important for sustainable resource management (Ostrom, 1990; Armitage, 2005):

1. A clear definition of right owners allowed to exploit resources.

2. An identification of the types of resources involved, and well-defined boundaries between the areas differentially managed.

3. Participation of all local stakeholders in defining rules, by the mean of local assemblies.

4. A graduated scale of sanctions for contraveners.

5. Mechanisms for conflict resolution.

6. Existing self-monitoring systems whereby resource users are accountable for their own actions.

This system, as a result of a long history of Environment-Society interactions illustrates concretely the indigenous knowledge and the traditional ecological 


\section{PABLO DOMINGUEZ ET AL.}

knowledge framework developed by Blaikie et al. (1997), and Peloquin and Berkes (2009), among others, as well as giving weight to the quadriptyc proposed by Berkes (2008) of knowledge-practices-institution-worldview for undertaking complexity found within traditional natural resource management systems. The various sets of practices, rituals and institutional arrangements have to be undertaken all together in order to assess their capacity to value scarce natural resources and to promote forms of adaptation to changing conditions or needs (Berkes et al., 2003, Olsson and Folke, 2001).

As we have seen, the agdal can be easily included within the Maussian 'total social fact' framework (Mauss, 1968). The highland territories are of great multidimensional importance for the Berber agro-pastoralists of the High Atlas, and they are to a large extent managed by various agdal systems. The joint symbolic weight of the local sacredness that accompanies the agdal, as we have seen above, associated with the economic benefits of these practices, appear to be fundamental for the sustainability of the highland pastures, and vice-versa. The development of an active economy, the coordination of the movement of a large number of herds in a reasonably just and peaceful way, and the maintenance of a cultural system seem to have co-evolved all together.

If we look at many other areas in Morocco, it is apparent that there have been many agdals that have broken down over the last 30 years, for example in the Middle Atlas. The explanations for this are multiple but are usually associated with a weakening of the vitality of customary practices. This has in turn led to such over-grazing, that the systems of animal rearing have been totally altered and in some extreme cases have also led to new restrictions for the herders. The animal production area has usually not decreased, but has changed its nature: construction of higher animal folds, modern fodder production or purchase, mechanisation, new transport, full integration into market economy, etc. (Bourbouze, 1999). Even if such a transformation could be a viable alternative for maintaining or improving the levels of agro-pastoral productivity, it would not be consistent with collective socio-cultural coherence and ecological sustainability that the traditional agdal systems seem to offer. In fact, such transformations and intensification of the ways of production in the mountains of the Maghreb generally lead to biodiversity loss, erosion of pastoral ecosystems, rupture of fundamental elements of the traditional system of social justice and loss of many patrimonial or cultural values (Auclair et al., 2007). Hence, traditional resource and land management systems can be of great interest for a renewed approach to development (Mosse, 2005). What we may perhaps conclude from this study, is that a hybrid quantitative and qualitative approach is necessary to assess the full dimensions of the agdal systems. There are different possible lines of research. First, to analyse accurately and objectively how the reinforcement of the saints' and agdal's symbolic traditions could contribute effectively to the maintenance of this pastoral management 


\section{THE AÏT IKISS TAGDALTS}

system that has proved its sustainability over the centuries. On a general note, we think that the advantages of a traditional cosmological and agro-pastoral production system that has provided sufficient, sustainable and successive levels of productive yields over time should be emphasised, in a context where this Berber religious tradition is continuously under pressure, as explained above.

Secondly, from a more materialistic point of view, it could be interesting to seek more profitable time-space scale readjustment of agdals in order to improve their natural resource production, since the scale has not always been chosen through an integrated eco-territorial analysis, but frequently on the basis of centuries old ethno-territorial and historical traditions that now could be revised in many cases. A third future line of research could be to explore the possibilities of the agdal in new approaches to sustainable agricultural development. Although these points should be explored from a different perspective to that described in this article, we think that there is a potential for establishing a policy of local agdal product certification by directing the production of the agdals towards products adapted to the local ethno-ecological conditions (local ways of production) and the external market (red meat, cheese or honey). This type of product certification could be based on the specific territory-resource-culture characteristics of the agdals. It is also possible to explore other formulas of using the agdals for the improvement of the agricultural productivity of these Berber agro-pastoral systems. Finally, one further line of research that seems plausible to us would be that the agdal system could help guarantee the conservation of the landscape and the current image of the territory, a major source of attraction for the growing tourism industry. Thus, after showing the services rendered by the agdal as a qualified and especially legitimate local institution in natural resource management, it could perhaps now be of interest to focus on the services it could offer with regard to the protection of certain touristic resources too. The high pastoral agdals play a role in sculpting and maintaining the local landscapes with images of abundant grass, open spaces, the solitude of uninhabited mountains and efficient agricultural production by the fact of being prohibited for year-round habitation (Dominguez, 2007). In other words, the agdal system is a uniquely Moroccan form of landscape shaping, and it would therefore be interesting to study in greater depth whether the agdal communitarian resource management system could be promoted as a profoundly Moroccan approach to the farming of territories, that is economically sustainable and ecologically enriching, as well as relatively just and cosmologically coherent.

\section{ACKNOWLEDGEMENTS}

Research was funded by Programme AGDAL (« biodiversité et gestion communautaire de l'accès aux ressources sylvopastorales » / Institut Français de la Biodiversité - Institut 


\section{PABLO DOMINGUEZ ET AL.}

de Recherche pour le Développement: financement $\mathrm{n}^{\circ} 2886$ ), the 'Formation à la recherche' scholarship from the Agence Universitaire de la Francophonie, the 'Field Work' scholarship from the UNESCO Fellowship Program and the 'BECAS MAE-AECID' from the Spanish Agency of International Cooperation and Development. The authors also thank the group AHCISP from the Universitat Autònoma de Barcelona who gave constant support to our work, the organisers of the Ethno-ecology workshop at the IXth biannual congress of the International Society for Ecological Economy (New Dehli, India), Ricardo Godoy and Victoria Reyes-García, at which a previous version of this paper was presented. We also wish to thank Mjid Mourad, Taoufik El-Khalili and Simohamed Ait Bella for their excellent work as translators and interviewers, all the members of the local NGO Association des amis du Zat and especially its president Ahmed Bellaoui, for having granted us so many facilities, both human and infrastructural, to enable us to approach the local communities. We finally thank very warmly all our informants who where so patient and cooperative.

\section{BIBLIOGRAPHY}

Alaoui-Haroni, S. 2009. Les pelouses humides dans le haut Atlas: Biodiversité végétale, dynamique spatiale et pratiques de gestion coutumière. Ph.D Dissertation, Univ. Cadi Ayyad, Laboratoire d'Écologie végétale, Marrakech.

Alaoui, S. and M. Alifriqui. 2009. 'Recent dynamics of the wet pastures at Oukaimeden plateau (High Atlas Mountains, Morocco)'. Biodiversity and Conservation 18(1): 167-189.

Armitage, D. 2005. 'Adaptative capacity and community-based natural resource management'. Environmental Management 35(6): 703-715.

Auclair, L., A. Bourbouze, P. Dominguez and D. Genin. 2007. Les agdals du Haut Atlas. Biodiversité et gestion communautaire des ressources forestières et pastorales. (CDROM document) Final report of the AGDAL program. Institut de Recherche pour le Dévelopement / Institut Français de la Biodiversité, Marseille, 196 p.

Bel, A. 1938. La religion musulmane en berbèrie. Esquisse d'histoire \& de sociologie religieuse. Paris : Ed. Librairie Orientaliste Geuthner.

Bellaoui, A. 1989. Les pays de l'Adrar-n-Dern. Etude géographique du Haut Atlas de Marrakech. Ph.D dissertation, Université de Tours, Département de Géographie, Tours, $500 \mathrm{p}$.

Berkes, F. 2008. Sacred Ecology. Traditional Ecological Knowledge and Management Systems, 2nd edn. London: Routledge.

Berkes, F., J. Colding and C. Folke. 2003. Navigating Social-Ecological Systems: Building Resilience for Complexity and Change. Cambridge: Cambridge University Press.

Blaikie P., K. Brown and M. Stocking. 1997. 'Knowledge in action: Local Knowledge as a development resource and barriers to its incorporation in natural resource research and development'. Agricultural Systems 55: 217-237.

Blondel J., 2006. 'The «design» of Mediterranean landscapes: a millennial story of Human and ecological systems during the Historic period'. Human Ecology 34: 713-730. 


\section{THE AÏT IKISS TAGDALTS}

Bourbouze A., 1997. 'Des agdal et des mouflons'. Courrier de l'environnement 30: 1-13.

Bourbouze, A. 1999. 'Gestion de la mobilité et résistance des organisations pastorales des éleveurs du Haut Atlas marocain face aux transformations du contexte pastoral maghrébin', in M. Niamir-Fuller (coord.), Managing mobility in african rangeland: the legitimization of transhumance (London: IT publications: FAO and Beijer intern. instit. Ecolog. Economics), pp. 236-265.

Cordier J.B., andD. Genin. 2008. 'Pratiques paysannes d'exploitation des arbres et paysages forestiers du Haut Atlas marocain'. Revue Forestière Française 60(5): 571-588.

Demay, S. 2004. Diagnostic agraire dans le Haut Atlas marocain. Territoire des Ait Ikiss. Master dissertation, INA, Paris-Grignon.

Dominguez, P. 2007. 'Transformación de instituciones religiosas tradicionales en el Alto Atlas de Marrakech (Marruecos) y su impacto en los ecosistemas sub-alpinos. Caso del sistema pastoral del agdal'. Perifèria 7: 26, http://antropologia.uab.es/Periferia/ Articles/ecologia_yagur_pdominguez.pdf.

Dominguez, P. and S. Hammi. 2010. 'L'agdal du Yagour, écologie et pastoralisme', in K. Fernández (coord.), Proceedings of the conference Ecología y Pastoralismo. Donostia: Ed. Koldo Mitxelena, 2: 34-56.

Dominguez P. 2010. 'Approche multidisciplinaire d'un système traditionnel de gestion des ressources naturelles communautaires: L'agdal pastoral du Yagour (Haut Atlas marocain', PhD dissertation, École des Hautes Études en Sciences Sociales/Université Autonome de Madrid.

Dresch, J. 1939. 'Caractères généraux de la vie pastorale dans le massif du grand Atlas'. Proc. 4ème congrès de la Fédération des soc. Savantes de l'Afrique du Nord, t. II. Alger, 493-497.

Evans-Pritchard, E. 1970. African political systems International. London: Oxford University Press, 302 p.

Folke, C., L. Pritchard, F. Berkes, J. Colding and U. Svedin. 2007. 'The problem of fit between ecosystems and institutions: Ten years later'. Ecology and Society 12(1): 30, http://www.ecologyandsociety.org/vol12/iss 1/art30/

Gellner, E. 1969. Saints of the Atlas. London: Weidenfield and Nicholson.

Genin D., Kerautret L., Hammi S., and Alifriqui M. In press. 'Biodiversité et pratiques d'agdal: un élément de l'environnement à l'épreuve de ses fonctions d'utilité pour les sociétés rurales du Haut Atlas'. In L. Auclair and M. Alifriqui (eds.), Agdal. Patrimoine socio-écologique del'Atlas marocain. Rabat, Morocco: IRCAM Editions.

Hammi, S., M. Al Ifriqui, V. Simonneaux and L. Auclair. 2007. 'Évolution des recouvrements forestiers et de l'occupation des sols entre 1964 et 2002 dans la haute vallée des Ait Bouguemez (Haut Atlas Central, Maroc)'. Sécheresse 18(4): 271-277.

Hammoudi, A. 1988. La Victime et ses masques : essai sur le sacrifice et la mascarade au Maghreb. Paris: Ed. du Seuil.

Ilahiane, H. 1999. 'The Berber agdal Institution: indigenous range management in the Atlas Mountains'. Ethnology 38(1): 21-45.

Jarrige R. (dir.) 1980. Alimentation des ruminants. Paris: Ed. INRA.

Kerautret, L. 2005. Entre Agdal et Moucharika. Master dissertation, Université de Provence, Laboratoire Population-Environnement-Développment, Marseille. 


\section{PABLO DOMINGUEZ ET AL.}

Mahdi, M. 1999. Pasteur de l'Atlas: Production Pastorale, Droit et Rituel. Casablanca: Fondation Conrad Adenauer.

Mahdi, M. and P. Dominguez. 2009. Regard anthropologique sur transhumance et modernité au Maroc. AGER, no. 8: 45-73.

Mauss, M., 1968. La fonction sociale du sacré. Paris: Ed. de Minuit.

Montagne, R. 1930. Les berbères et le Makhzen dans le sud du Maroc. Paris: Ed. Félix Alcan.

Mosse, D., 2005. Cultivating Development. An Ethnography of Aid Policy and Practice. London: Pluto Press.

Neves-Garca, K. 2004. 'Revisiting the tragedy of the commons: Ecological dilemmas of whale watching in the Azores'. Human Organization 63: 289-300.

Olsson, P., and C. Folke. 2001. 'Local ecological knowledge and institutional dynamics for ecosystem management: a study of Lake Racken watershed, Sweden'. Ecosystems 4: $85-104$.

Ostrom, E. 1990. Governing the Commons. The Evolution of Institutions for Collective Action. Cambridge: Cambridge University Press.

Peloquin C., and F. Berkes. 2009. 'Local knowledge, subsistence harvests, and socialecological complexity in James Bay'. Human Ecology 37: 533-545.

Rachik, Hassan. 1992. Le sultan des autres, rituel et politique dans le Haut Atlas. Casablanca: Ed. Afrique Orient.

Romagny, B., L. Auclai and A. Elgueroua. 2008. 'La gestion des ressources naturelles dans la vallée des Aït Bouguemez (Haut Atlas): la montagne marocaine à la recherche d'innovations institutionnelles'. Mondes en développement 63(1): 63-80.

Simenel R. 2008, 'L'origine est aux frontières : espace, histoire et société dans une terre d'exil du Sud Marocain', PhD dissertation, Université de Paris X.

Venema B., 2002. 'The vitality of local political institutions in the MiddleAtlas, Morocco'. Ethnology 41: 103-117. 